\title{
IN SILICO ДОСЛІДЖЕННЯ МОЖЛИВИХ ШЛЯХІВ МЕТАБОЛІЗМУ АТРИСТАМІНУ В ОРГАНІЗМІ ЛЮДИНИ
}

Вступ. Об'єктом представленого дослідження є атристамін (2-метил-3-(феніламінометил)-1Н-хінолін-4-он), який вивчають як перспективний антидепресант із церебропротекторними, ноотропними, аналгетичними, антигіпоксичними та актопротекторними властивостями. Обов'язковою умовою подальшого впровадження його як кандидата в ліки є дослідження фрармакокінетичних характеристик молекули. Це неможливо здійснити без цілісного розуміння процесів біотранссрормації, яким піддається досліджувана сполука в організмі людини.

мета дослідження - провести in silico дослідження можливих шляхів метаболізму перспективного антидепресанта атристаміну за допомогою онлайн-ресурсів, що перебувають у вільному доступі.

Meтоди дослідження. 3 метою іn silico дослідження можливих напрямків біотрансформації атристаміну в організмі людини використовували он-лайн такі веб-сервіси: "Xenosite P450 Metabolism 1.0"; "Xenosite UGT 2.0"; "Way2Drug SOMP" та "Way2Drug RA". 3 огляду на те, що структурною особливістю хінолін-4(1Н)-онів є можливість існування прототропної таутомерії в гетероциклі, обчислення проводили для обох теоретично можливих таутомерних фрорм молекули атристаміну - 2-метил-3-(феніламінометил)1Н-хінолін-4-ону та 4-гідрокси-2-метил-3-(френіламінометил)-хіноліну.

Результати й обговорення. Наявність вторинної аміногрупи в молекулі 2-метил-3-(френіламінометил)-1Н-хінолін-4-ону і 4-гідроксигрупи в молекулі іншого таутомера (4-гідрокси-2-метил-3-(френіламінометил)-хіноліну) зумовлює високу ймовірність глюкуронування з утворенням, відповідно, N- та О-глюкуронідів. Для 2-метил-3-(френіламінометил)-1Н-хінолін-4-ону як більш стійкої фоорми показано, що основними шляхами метаболізму можуть бути ароматичне гідроксилювання, аліфратичне гідроксилювання, окиснювальне дезамінування, N-гідроксилювання та епоксидування. Найбільшої уваги заслуговує напрямок аліфратичного гідроксилювання, оскільки, на відміну від усіх інших шляхів, у результаті цього прогнозується утворення генерації метаболітів з новими фрармакологічними властивостями (похідні кінуренової кислоти).

Висновок. Результати in silico дослідження можливих иляхів метаболізму атристаміну в організмі людини свідчать на користь того фракту, що досліджувана сполука з високою ймовірністю інтенсивно метаболізується з участю ензимних систем цитохрому P450, що обов'язково необхідно врахувати в подальшому при плануванні експериментів in vivo.

КЛЮЧОВІ СЛОВА: атристамін; 2-метил-3-(феніламінометил)-1Н-хінолін-4-он; метаболізм; in silico дослідження; Xenosite; Way2Drug.

ВСТУП. Біотрансформація являє собою біохімічну модисрікацію ксенобіотиків живими організмами з участю специсрічних ензимних систем. У разі застосування зазначеного терміна до активних фрармацевтичних інгредієнтів частіше використовують поняття "метаболізм лікарського засобу" [1]. Під час метаболічних перетворень біологічно активних молекул в організмі людини можуть виникати метаболіти з фрізико-хімічними та фрармакологічними властивостями, які суттєво відрізняються від таких у "материнських" сполук, що має важливе значення як з огляду на есрективність, так і в аспекті безпечності лікарських засобів [2].

(с) І. М. Подольський, С. Ю. Штриголь, 2019.
Для зменшення ризику відкликання сполук-кандидатів у ліки на стадії клінічних випробувань внаслідок метаболічних характеристик молекул необхідні ефективні й надійні методи вивчення метаболізму молекули біологічно активної сполуки in silico, in vitro та in vivo. Експериментальні дослідження можливих шляхів біотранссормації нових молекул in vitro та in vivo завжди є нетривіальними і ресурсозатратними завданнями. Саме тому застосування комп'ютерного прогнозування можливих шляхів метаболізму потенційного кандидата в ліки на початкових етапах є цілком виправданим та ефективним підходом, який дозволяє ідентифрікувати сайти метаболізму (site of metabolism, SOM), 
прогнозувати структури метаболітів, що утворюються, оцінювати інтенсивність метаболізму і специсрічність субстратів до ензимів цитохрому P450 [3].

Традиційно реакції метаболізму лікарських засобів поділяють на реакції I фрази (окиснення, гідроліз, відновлення), яку ще називають функціоналізацією, та реакції II фрази (кон'югація) [4]. Під час I фрази цитохроми P450 (CYP) активують молекулу ксенобіотика шляхом введення до структури реакційноздатної та полярної групи. Сульфотрансорерази, N-ацетилтрансорерази та УДФ-глюкуронілтранссрерази (UGT) є основними ензимами II фрази, залученими до кон'югації активованого метаболіту шляхом збільшення молекулярної маси і зменшення його реакційної здатності [5]. 3 огляду на те, що цитохроми P450 залучені до I фрази метаболізму більш як 90 \% лікарських засобів, представлених на ринку, саме різні ізофрорми ензимів цієї родини застосовують як моделі у величезній кількості розрахункових підходів до прогнозування SOM [6].

На сьогодні розроблено достатню кількість програмних продуктів, що використовують підходи, зосереджені на прогнозуванні, або метаболічних реакцій, або сайтів метаболізму. Серед них Xenosite [7, 8] і Way2Drug: SOMP [9] прогнозують SOM для CYP та UGT. Програмний продукт Way2Drug: RA [1] пропонує альтернативний підхід до прогнозування можливих шляхів біотрансорормації - визначення атомів, що реагують (reacting atoms, RA), тобто розрахунок вірогідності перебігу реакції з участю відповідних ензимів для кожного окремого атома в молекулі. Застосування комбінованого підходу до прогнозування, тобто експертного аналізу даних, одержаних за допомогою декількох ресурсів з різними алгоритмами розрахунків, дозволяє значно підвищити точність результатів.

Об'єктом цього дослідження є атристамін (2-метил-3-(френіламінометил)-1Н-хінолін-4-он), який вивчають як перспективний антидепресант $[10,11]$ із церебропротекторними [12], ноотропними [13], аналгетичними [14], антигіпоксичними [15] та актопротекторними [11] властивостями. Обов'язковою умовою подальшого впровадження його як кандидата в ліки є дослідження фрармакокінетичних характеристик молекули. Це неможливо здійснити без цілісного розуміння процесів біотрансорормації, яким піддається досліджувана сполука в організмі людини.

Мета дослідження - провести in silico дослідження можливих шляхів метаболізму перспективного антидепресанта атристаміну за допомогою онлайн-ресурсів, що перебувають у вільному доступі.

МЕТОДИ ДОСЛІДЖЕННЯ. 3 оглЯДУ на те, що структурною особливістю хінолін-4(1Н)-онів $€$ можливість існування прототропної таутомерії в гетероциклі, обчислення проводили для обох теоретично можливих таутомерних форм молекули атристаміну - 2-метил-3-(феніламінометил)-1Н-хінолін-4-ону та 4-гідрокси-2метил-3-(феніламінометил)-хіноліну (рис. 1). 4-Гідрокси/оксо-таутомерію в ряду похідних 3-заміщених 2-метилхінолін-4(1Н)-онів раніше було досліджено за допомогою ЯМР ${ }^{13} \mathrm{C}$ спектроскопії і квантово-хімічними методами в різних наближеннях для ізольованих молекул і розчинів 3 використанням емпіричної корекції еоректів розчинників [16]. Незважаючи на той фракт, що результати цих досліджень свідчать на користь більшої стабільності 4-оксо-срорми, не можна виключати можливість утворення 4-гідрокситаутомера в біологічних рідинах організму людини.

3 метою in silico дослідження можливих напрямків біотрансформації атристаміну в організмі людини використовували он-лайн такі веб-сервіси:

1. "Xenosite P450 Metabolism 1.0" [7] - прогнозує SOM у молекулі для CYP ізоформ 1A2, 2A6, 2B6, 2C8, 2C9, 2C19, 2D6, 2E1, 3A4, розраховує коефіцієнт імовірності, що варіює між 0 та 1 (чим він більший, тим вища ймовірність виступати сайтом метаболізму). Режим доступу: https://swami.wustl.edu/xenosite/jobs.

2. "Xenosite UGT 2.0" [8] - прогнозує SOM у молекулі для UGT, застосовують для ідентифрікації SOM шляхом асоціації з коефіцієнтами ймовірності (варіює між 0 та 1). Режим доступу: https://swami.wustl.edu/xenosite/jobs.

3. "Way2Drug SOMP" [9] - прогнозує SOM y молекулі для СYP ізофрорм 1А2, 2C9, 2C19, 2D6, 3A4 та UGT, розраховує коефіцієнт імовірності (від 0 до 1), який визначає здатність окремого<smiles>C#CC#C</smiles><smiles>Cc1nc2ccccc2c(O)c1CNc1ccccc1</smiles>

Рис. 1. Таутомерні фрорми молекули атристаміну. 
атома виступати SOM для конкретного ензиму. Режим доступу: http://www.way2drug.com/SOMP.

4. "Way2Drug RA" [1] - дозволяє ідентисрікувати в досліджуваній молекулі RA для більшості класів реакцій біотрансформації, що каталізуються п'ятьма основними ізоформами цитохрому Р450 людини (СYP1A2, СYP2C19, СYР2C9, CYP2D6 і CYP3A4) та всіма ізоформами родини УДФ-глюкуронілтранссрераз. Основним показником, який розраховує програмний продукт для кожного класу реакцій, $€$ DeltaP, що дорівнює різниці між Ра (вірогідність, 3 якою зазначений атом бере участь у реакції) та Рі (вірогідність, 3 якою зазначений атом не бере участі в реакції). Режим доступу: http://www.way2drug.com/RA.

РЕЗУЛЬТАТИ Й ОБГОВОРЕННЯ. РЕЗУЛЬТАТИ in silico дослідження можливих шляхів метаболізму атристаміну в організмі людини свідчать на користь того фракту, що досліджувана сполука з високою ймовірністю інтенсивно метаболізується з участю ензимних систем цитохрому P450, що обов'язково необхідно врахувати в подальшому при плануванні експериментів in vivo.

Як видно з таблиці 1, для молекули 2-метил-3-(среніламінометил)-1Н-хінолін-4-ону най- більш імовірними шляхами фрункціоналізації молекули є ароматичне гідроксилювання 3 участю атомів ароматичної частини гетероциклу і френільного замісника амінометильного фррагмента молекули, аліфатичне гідроксилювання метильної групи в положенні 2 (нумерація за системою ЮЮАК), N-гідроксилювання Нітрогену аміногрупи, епоксидування подвійного зв'язку 2-3 гетероциклу та N-деалкілування амінометильного фррагмента, що в даному випадку можна розглядати як окиснювальне дезамінування з утворенням відповідної карбонільної сполуки.

Показано, що молекула 2-метил-3-(френіламінометил)-1Н-хінолін-4-ону може вступати в реакцію кон'югації з глюкуроновою кислотою 3 участю атома Нітрогену амінометильного фррагмента (N-глюкуронування). Для іншого таутомера (4-гідрокси-2-метил-3-(френіламінометил)-хіноліну), поряд із цим, існує можливість кон'югації з глюкуроновою кислотою з участю 4-гідроксигрупи (О-глюкуронування). Можливість перебігу кон'югації з утворенням відповідних глюкуронідів також підтверджується результатами прогнозування з використанням он-лайн сервісу “Xenosite UGT 2.0" (рис. 2).

Таблиця 1 - Результати прогнозування реакцій метаболізму таутомерних форм молекули атристаміну з використанням веб-сервісу "Way2Drug RA"

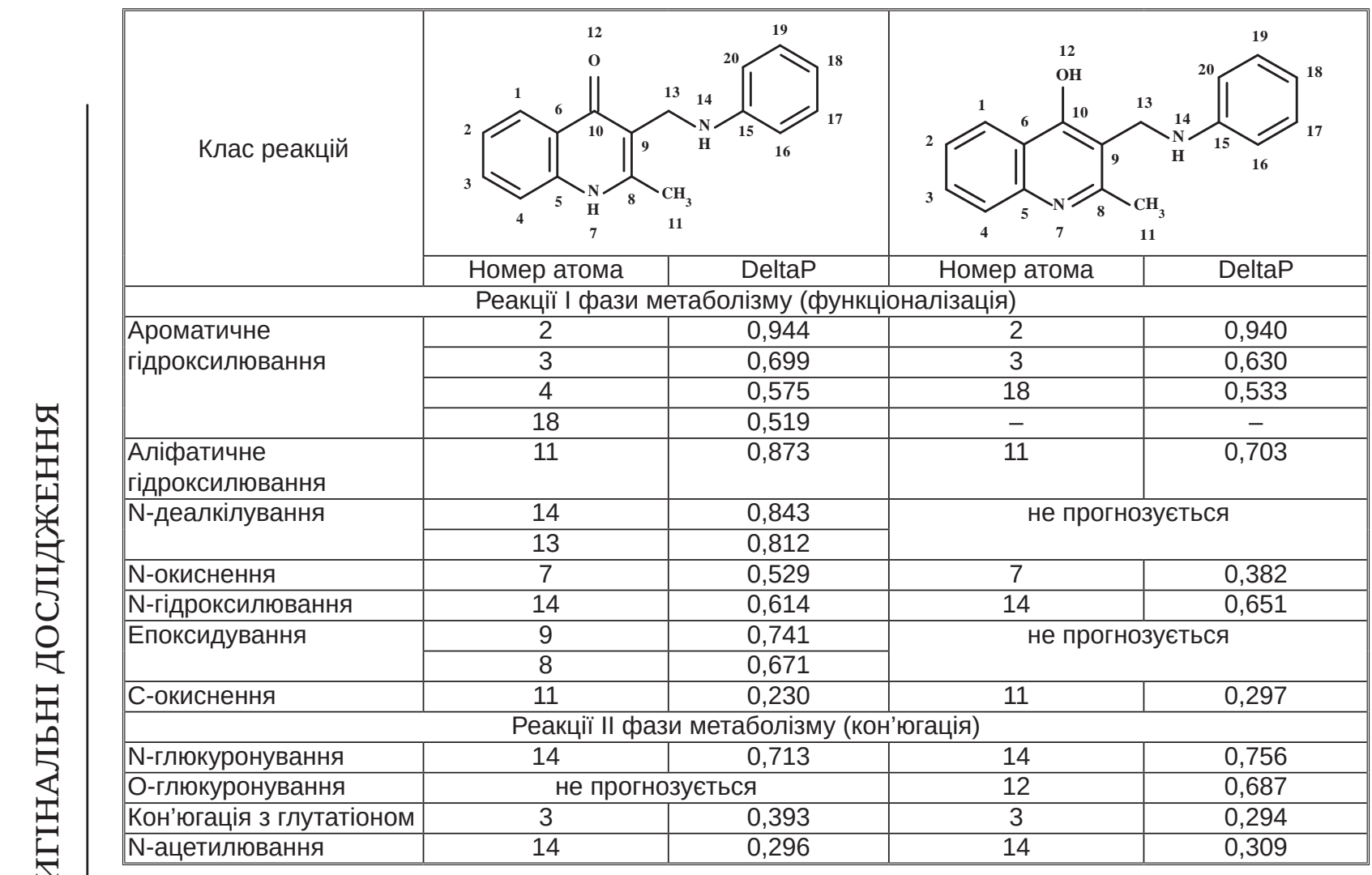

Примітка. Наведено результати для всіх атомів з DeltaP>0,5 або найвищий показник, атоми в молекулах пронумеровано відповідно до обчислень веб-сервісу. 

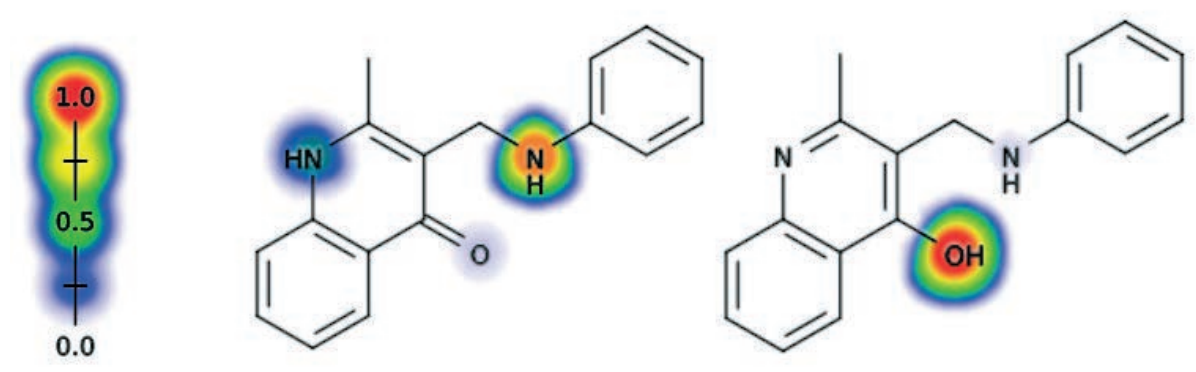

Рис. 2. Результати прогнозування за допомогою програми “Xenosite UGT 2.0".

Аналіз результатів прогнозування з використанням веб-сервісу "Way2Drug RA" дозволив припустити хімічні структури метаболітів та побудувати схему можливих шляхів метаболізму атристаміну (рис. 3). Додатково було спрогнозовано подальші напрямки біотрансфрормації найбільш імовірних метаболітів. На рисунку наведено основні реакції метаболізму для 2-метил-3-(френіламінометил)-1Н-хінолін-4-ону як більш стабільної таутомерної фрорми, значення DeltaP та хімічні структури відповідних метаболітів; наведено тільки ті процеси, для яких DeltaP>0,7; атоми в гетероциклі пронумеровано згідно з номенклатурою ІЮПАК.

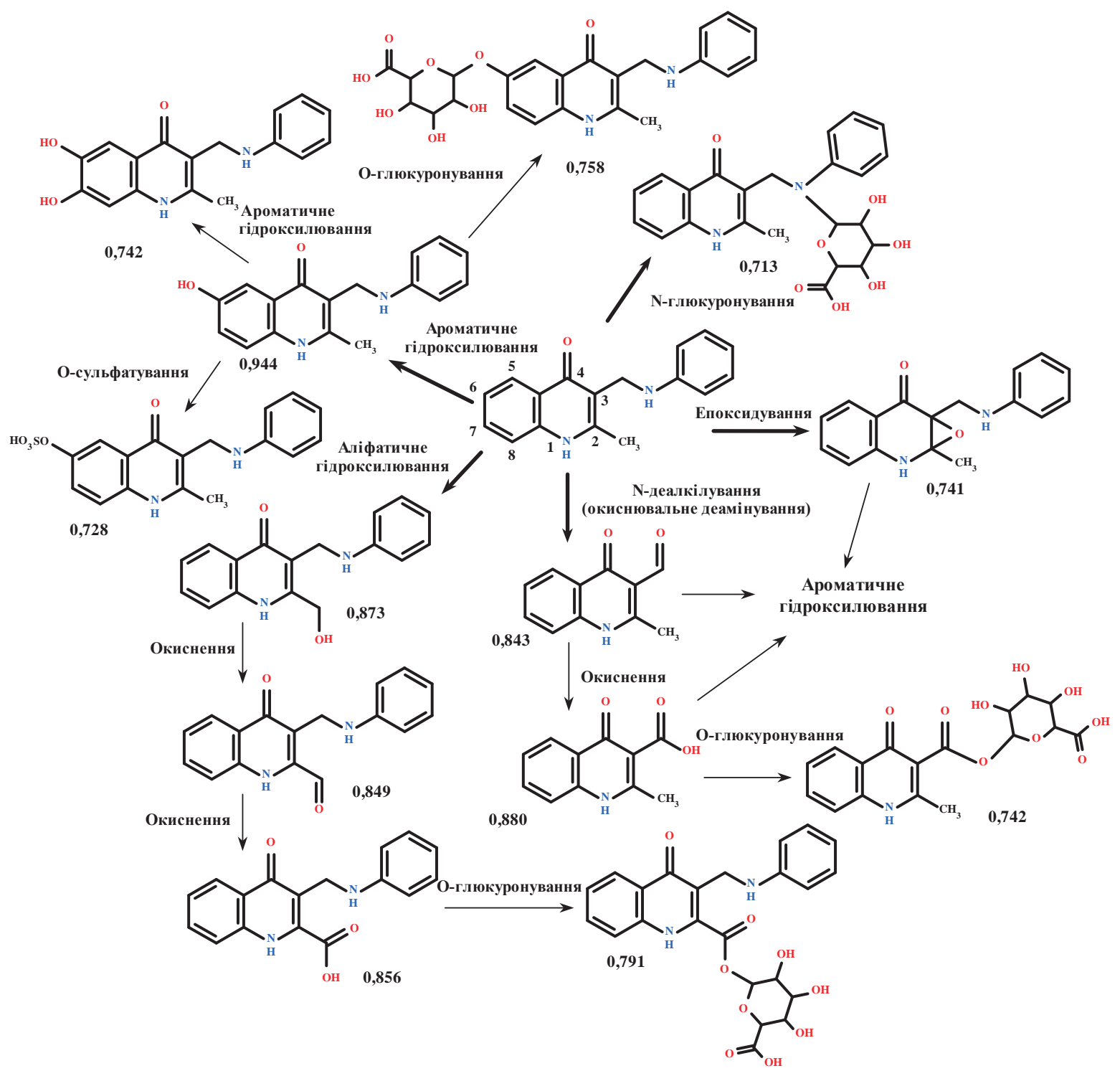

Pис. 3. Імовірні шляхи метаболізму атристаміну в організмі людини за результатами веб-сервісу “Way2Drug RA”. 
Відомо, що в результаті метаболізму вихідна сполука може втрачати свої фрармакологічні властивості або модифрікуватись з утворенням генерації метаболітів з іншими біологічними і токсикологічними характеристиками. У нашому випадку можна припустити, що послідовне ароматичне гідроксилювання навряд чи значною мірою впливає на фрармакологічні властивості молекули аж до кон'югації з відповідними кислотами, у вигляді яких дані метаболіти елімінують з організму людини. Це пов'язано з тим, що в результаті таких перетворень не зачіпається фармакофорний фррагмент молекули. Окиснювальне дезамінування, навпаки, повинно значною мірою впливати на виявлення психо- та нейротропних властивостей молекули, оскільки призводить до втрати критичного для прояву зазначеного спектра фрармакологічної активності структурного фррагмента молекули.

Найбільший інтерес викликає біотранссрормація молекули з участю метильної групи в положенні 2. Алісратичне гідроксилювання цього фррагмента з подальшим окисненням може генерувати метаболіти, структурно подібні до кінуренової кислоти - ендогенної речовини 3 нейротропними властивостями [17]. Таким чином, можна припустити, що деякі віддалені ефекти, які спостерігають при застосуванні атристаміну, можуть бути наслідком фрармакологічної дії його метаболітів.
Результати прогнозування SOM із використанням веб-сервісу "Way2Drug SOMP" свідчать на користь високої реакційної здатності метиленової групи амінометильного фррагмента 2-метил-3-(феніламінометил)-1Н-хінолін-4-ону в реакціях гідроксилювання з участю більшості ізоформ цитохрому P450 (табл. 2).

Цей фракт при зіставленні з результатами, наведеними в таблиці 1, додатково свідчить на користь високої ймовірності окиснювального дезамінування, оскільки гідроксилювання Карбону в $\alpha$-положенні до аміногрупи в класичних уявленнях медичної хімії розглядають як першу стадію N-деалкілування (дезамінування) 3 подальшим утворенням первинного аміну та відповідної карбонільної сполуки.

Аналіз результатів, одержаних для молекули 2-метил-3-(феніламінометил)-1Н-хінолін-4-ону з використанням веб-сервісу "Xenosite P450 Metabolism 1.0" (рис. 4), виявив додатково високу ймовірність участі атома Карбону в пара-положенні френільного замісника в амінометильному фррагменті в реакціях гідроксилювання із залученням CYP 1A2, 2C9, 2D6, 2E1 та 3A4, а також мікросом печінки людини (HLM).

Таким чином, результати, одержані з використанням різних алгоритмів обчислення, добре узгоджуються між собою та із сучасними уявленнями медичної хімії стосовно метаболізму лікарських засобів. Наведені висновки та положення

Таблиця 2 - Результати прогнозування SOM для таутомерних фрорм молекули атристаміну 3 використанням веб-сервісу "Way2Drug SOMP"

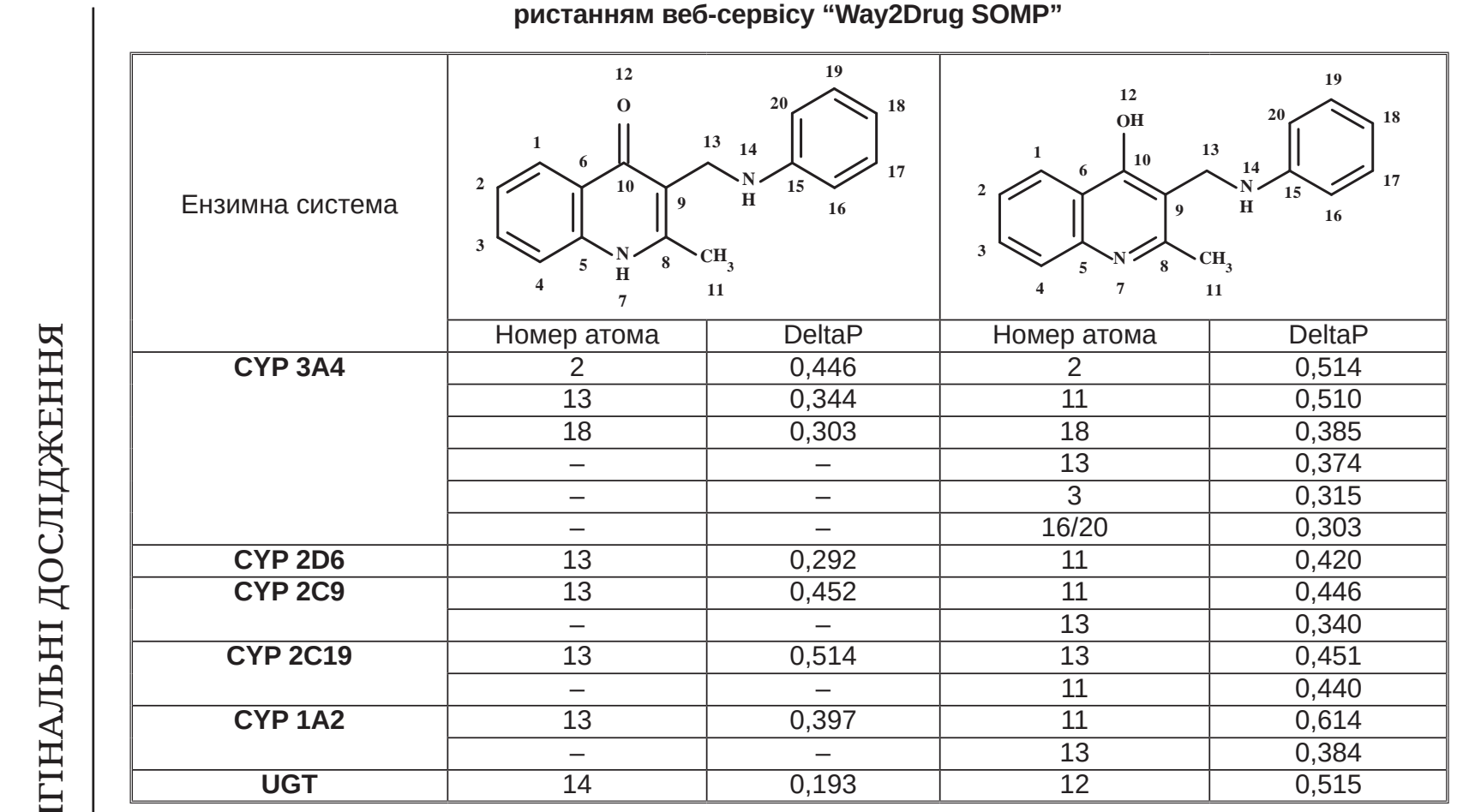

Примітка. Наведено результати для всіх атомів з DeltaP>0,3 або найвищий показник, атоми в молекулах пронумеровано відповідно до обчислень веб-сервісу. 

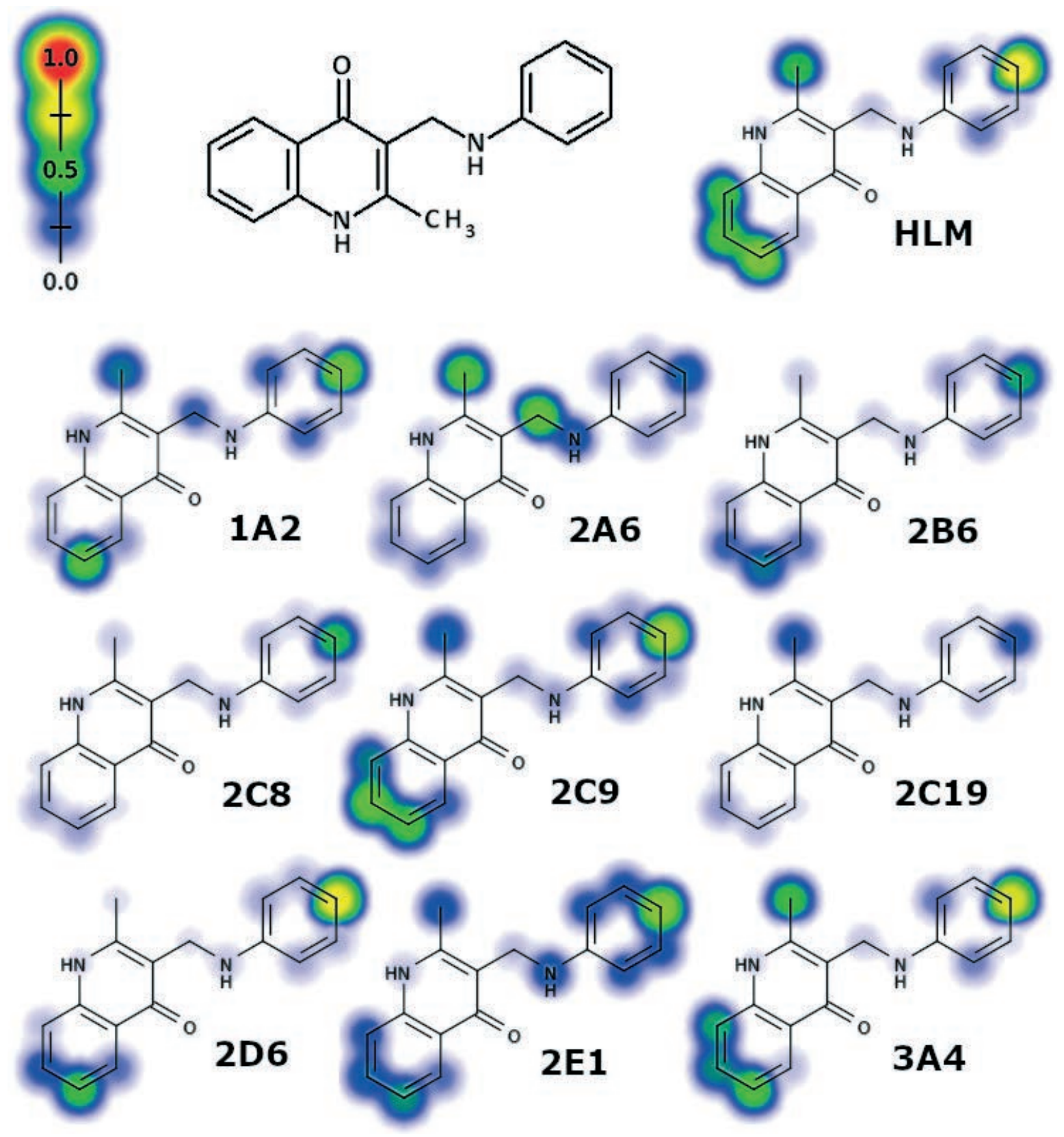

Рис. 4. Результати прогнозування з використанням веб-сервісу “Xenosite P450 Metabolism 1.0”.

Графрічно зображено ймовірність атомів виступати реакційними центрами перетворень 3 участю різних ізоформ цитохрому Р450 та мікросом печінки людини (HLM).

обов'язково необхідно врахувати при розробці методик дослідження фрармакокінетичних властивостей атристаміну in vivo.

ВИСНОВКИ. У роботі наведено результати in silico дослідження можливих шляхів метаболізму перспективного антидепресанта атристаміну з використанням он-лайн сервісів "Way2Drug SOMP", "Way2Drug RA", "Xenosite P450 Metabolism 1.0" та "Xenosite UGT 2.0". Розрахунки проводили з урахуванням можливості існування різних таутомерних орорм молекули досліджуваної речовини в біологічних рідинах організму людини. Показано, що молекула атристаміну з високою ймовірністю інтенсивно метаболізується 3 участю ензимних систем цитохрому P450, що обов'язково необхідно врахувати в подальшому при плануванні експериментів in vivo. Наявність вторинної аміногрупи в молекулі 2-метил-3-(френіламінометил)-1Н-хінолін-4-ону і 4-гідроксигрупи в молекулі іншого таутомера (4-гідрокси-2-метил3-(феніламінометил)-хіноліну) зумовлює високу ймовірність глюкуронування 3 утворенням, відповідно, N- та О-глюкуронідів. Для 2-метил3-(френіламінометил)-1Н-хінолін-4-ону як більш 
стійкої фрорми показано, що основними шляхами метаболізму можуть бути ароматичне гідроксилювання, аліфатичне гідроксилювання, окиснювальне дезамінування, N-гідроксилювання та епоксидування. Найбільшої уваги заслуговує напрямок аліфатичного гідроксилювання, оскільки, на відміну від усіх інших шляхів, у результаті цього прогнозується утворення генерації метаболітів з новими фрармакологічними властивостями (похідні кінуренової кислоти).

\section{СПИСОК ЛІТЕРАТУРИ}

1. Prediction of reacting atoms for the major biotransformation reactions of organic xenobiotics / A. V. Rudik, A. V. Dmitriev, A. A. Lagunin [et al.] // Journal of Cheminformatics. - 2016. - 8. - Art. №68. - Access mode : https://doi.org/10.1186/s13321-016-0183-x

2. Predicting drug metabolism: experiment and/or computation? / J. Kirchmair, A. H. Göller, D. Lang [et al.] // Nature Reviews Drug Discovery. - 2015. - 14, Issue 6. P. 387-404. - Access mode : https://doi.org/10.1038/ nrd4581

3. Adams, S. E. Molecular Similarity and Xenobiotic Metabolism (Doctoral thesis) / S. E. Adams. - University of Cambridge. - 2010. - 251 p. - Access mode : https:// doi.org/10.17863/CAM.16274

4. Drug Metabolism: Current Concepts / M. R. Caira, C. Ionescu. - eds. - Springer Netherlands: 2005. 422 p. - Access mode : https://doi.org/10.1007/1-4020$4142-\mathrm{X}$

5. In silico prediction of Heterocyclic Aromatic Amines metabolism susceptible to form DNA adducts in humans / V. Delannée, S. Langouët, A. Siegel, N. Théret // Toxicology Letters. - 2019. - 300. - P. 18-30. - Access mode : https://doi.org/10.1016/j.toxlet.2018.10.011

6. Cytochrome P450 site of metabolism prediction from 2D topological fingerprints using GPU accelerated probabilistic classifiers / J. D. Tyzack, H. Y. Mussa, M. J. Williamson [et al.] // Journal of Cheminformatic. 2014. - 6. - Art. No. 29. - Access mode : https://doi. org/10.1186/1758-2946-6-29

7. Zaretzki, J. XenoSite: accurately predicting CYPmediated sites of metabolism with neural networks / J. Zaretzki, M. Matlock, S. J. Swamidass // Journal of Chemical Information and Modeling. - 2013. - 53, Issue 12. - P. 3373-3383. - Access mode : https://doi. org/10.1021/ci400518g

8. A simple model predicts UGT-mediated metabolism / N. L. Dang, T. B. Hughes, V. Krishnamurthy, S. J. Swamidass // Bioinformatics. - 2016. - 32, Issue 20. - P. 3183-3189. - Access mode : https://doi. org/10.1093/bioinformatics/btw350

9. SOMP: web server for in silico prediction of sites of metabolism for drug-like compounds / A. Rudik, A. Dmitriev, A. Lagunin [et al.] // Bioinformatics. - 2015. - 31,

\section{REFERENCES}

1. Rudik, A.V., Dmitriev, A.V., Lagunin, A.A., Filimonov, D.A., \& Poroikov, V.V. (2016). Prediction of reacting atoms for the major biotransformation reactions of organic xenobiotics. J. Cheminformatics, 8, Art. No. 68. Retrieved from: https://doi.org/10.1186/s13321-0160183-x
Issue 12. - P. 2046-2048. - Access mode : https://doi. org/10.1093/bioinformatics/btv087

10. 2-Метил-3-срениламинометилхинолин-4-он потенциальный антидепрессант с ноотропными свойствами / С. Ю. Штрыголь, В. А. Зубков, И. Н. Подольский, И. С. Гриценко // Эксперим. и клинич. фрармакология. - 2012. - 75, № 4. - С. 7-9.

11. Podolsky I. M. The psycho- and neurotropic profiling of novel 3-(N-R,R'-aminomethyl)-2-methyl-1Hquinolin-4-ones in vivo / I. M. Podolsky, S. Yu. Shtrygol', V. O. Zubkov // Saudi Pharmaceutical Journal. - 2018. 26, Issue 1. - P. 107-114. - Access mode : https://doi. org/10.1016/j.jsps.2017.10.005

12. Podolsky, I. M. Neuroprotective activity of 2-methyl-3-phenylaminomethylquinolin-4-one in experimental traumatic brain injury in rats / I. M. Podolsky, S. Yu. Shtrygol // Journal of Chemical and Pharmaceutical Research. - 2015. - 7, Issue 4. - P. 518-524.

13. Podolsky I. The memory and learning enhancing effects of Atristamine // I. Podolsky, S. Shtrygol' // Pharmacia. -2019. -66, Issue 1. -P. 13-18. -Access mode : https://doi.org/10.3897/pharmacia.66.e35048

14. Podolsky I. The analgesic properties of a promising antidepressant - 2-methyl-3-(phenylaminomethyl)-1H-quinolin-4-one / I. Podolsky, S. Shtrygol' // The Pharma Innovation Journal. -2017. - 6, Issue 8 (C). P. 156-160.

15. Дослідження антигіпоксичної активності 2-метил-3-феніламінометилхінолін-4-ону - перспективного антидепресанта з ноотропними властивостями / І. М. Подольський, С. Ю. Штриголь, В. Ф. Осташко, Н. В. Бездітко // Укр. біофармац. журн. - 2013. № 2 (25). - C. 46-49.

16. The experimental and theoretical study of tautomerism of 3-substituted 2-methyl-quinoline-4(1H)-ones / V. O. Zubkov, O. B. Rozhenko, N. I. Ruschak, I. S. Gritsenko // Журнал органічної та фрармацевтичної хімії. 2016. - 14, № 2 (54). - C. 53-59.

17. Recent evidence for an expanded role of the kynurenine pathway of tryptophan metabolism in neurological diseases / M. D. Lovelace, B. Varney, G. Sundaram [et al.] // Neuropharmacology. - 2017. - 112, part B. P. 373-388. - Access mode : https://doi.org/10.1016/j. neuropharm. 2016.03.024

2. Kirchmair, J., Göller, A.H., Lang, D., Kunze, J., Testa, B., Wilson, I.D., ... Schneider, G. (2015). Predicting drug metabolism: experiment and/or computation? Nat. Rev. Drug Discov., 14 (6), 387-404. Retrieved from: https://doi.org/10.1038/nrd4581 
3. Adams, S.E. (2010). Molecular similarity and xenobiotic metabolism (Doctoral thesis). Retrieved from: https://doi.org/10.17863/CAM.16274

4. Caira, M.R., \& Ionescu, C. (2005). Drug Metabolism: Current Concepts. Springer Netherlands. Retrieved from: https://doi.org/10.1007/1-4020-4142-X

5. Delannée, V., Langouët, S., Siegel, A., \& Théret, N. (2019). In silico prediction of Heterocyclic Aromatic Amines metabolism susceptible to form DNA adducts in humans. Toxicology Letters, 300, 18-30. Retrieved from: https://doi.org/10.1016/j.toxlet.2018.10.011

6. Tyzack, J.D., Mussa, H.Y., Williamson M.J., Kirchmair, J., Glen, R.C. (2014). Cytochrome P450 site of metabolism prediction from $2 \mathrm{D}$ topological fingerprints using GPU accelerated probabilistic classifiers. Retrieved from: J. Cheminformatics, 6, Art. №29. Retrieved from: https://doi.org/10.1186/1758-2946-6-29

7. Zaretzki, J., Matlock, M., Swamidass, S.J. (2013). XenoSite: accurately predicting CYP-mediated sites of metabolism with neural networks. J. Chem. Inf. Model., 53(12), 3373-3383. Retrieved from: https://doi. org/10.1021/ci400518g

8. Dang, N.L., Hughes, T.B., Krishnamurthy, V., Swamidass, S.J. (2016). A simple model predicts UGTmediated metabolism. Bioinformatics, 32 (20), 31833189. Retrieved from: https://doi.org/10.1093/bioinformatics/btw350

9. Rudik, A., Dmitriev, A., Lagunin, A., Filimonov, D., Poroikov, V. (2015). SOMP: web server for in silico prediction of sites of metabolism for drug-like compounds. Bioinformatics, 31 (12), 2046-2048. Retrieved from: https://doi.org/10.1093/bioinformatics/btv087

10. Shtrygol, S.Yu., Zubkov, V.A., Podolskiy, I.N., \& Gritsenko, I.S. (2012). 2-Metil-3-fenilaminometilkhinolin4-on - potentsialnyy antidepressant s nootropnymi svoystvami [2-Methyl-3-phenylaminomethylquinolin-4one as potential antidepressant with nootropic properties] Eksperimentalnaya i klinicheskaya farmakologiya - Experimental and Clinical Pharmacology, 75 (4), 7-9 [in Russian].
11. Podolsky, I.M., Shtrygol', S.Yu., \& Zubkov, V.O. (2018). The psycho- and neurotropic profiling of novel 3-(N-R, R'-aminomethyl)-2-methyl-1H-quinolin-4-ones in vivo. Saudi Pharmaceutical Journal, 26 (1), 107-114. Retrieved from: https://doi.org/10.1016/j. jsps.2017.10.005

12. Podolsky, I.M., \& Shtrygol, S.Yu. (2015). Neuroprotective activity of 2-methyl-3-phenylaminomethylquinolin-4-one in experimental traumatic brain injury in rats. Journal of Chemical and Pharmaceutical Research, 7 (4), 518-524.

13. Podolsky, I., Shtrygol', S. (2019). The memory and learning enhancing effects of Atristamine. Pharmacia, 66 (1), 13-18. Retrieved from: https://doi.org/10.3897/ pharmacia.66.e35048

14. Podolsky, I., Shtrygol', S. (2017). The analgesic properties of a promising antidepressant - 2-methyl-3(phenylaminomethyl)-1H-quinolin-4-one. The Pharma Innovation Journal, 6 (8C), 156-160.

15. Podolskyi, I.M., Shtryhol, S.Yu., Ostashko, V.F., \& Bezditko, N.V. (2013). Doslidzhennia antyhipoksychnoi aktyvnosti 2-metyl-3-fenilaminometylkhinolin-4-onu perspektyvnoho antydepresanta z nootropnymy vlastyvostiamy [The research of antihypoxic activity of 2-methyl-3-phenylaminomethylquinolin-4-one - perspective antidepressant with nootropic properties]. Ukrainskyi biofarmatsevtychnyizhurnal-Ukrainian Biopharmaceutical Journal, 2 (25), 46-49 [in Ukrainian].

16. Zubkov, V.O., Rozhenko, O.B., Ruschak, N.I., \& Gritsenko, I.S. (2016). The experimental and theoretical study of tautomerism of 3-substituted 2-methyl-quinoline$4(1 \mathrm{H})$-ones. Zhurnal orhanichnoi ta farmatsevtychnoi khimii - Journal of Organic and Pharmaceutical Chemistry, 14 (2), 53-59.

17. Lovelace, M.D., Varney, B., Sundaram, G., Lennon, M.J., Lim, C.K., Jacobs, K., ... Brew, B.J. (2017). Recent evidence for an expanded role of the kynurenine pathway of tryptophan metabolism in neurological diseases. Neuropharmacology, 112 (B), 373-388. Retrieved from: https://doi.org/10.1016/j.neuropharm.2016.03.024

\section{И. Н. Подольский, С. Ю. Штрыголь}

НАЦИОНАЛЬНЫЙ ФАРМАЦЕВТИЧЕСКИЙ УНИВЕРСИТЕТ, ХАРЬКОВ

\section{IN SILICO ИССЛЕДОВАНИЕ ВОЗМОЖНЫХ ПУТЕЙ МЕТАБОЛИЗМА АТРИСТАМИНА В ОРГАНИЗМЕ ЧЕЛОВЕКА}

\section{Резюме}

Вступление. Объектом представленного исследования является атристамин (2-метил-3-(френиламинометил)-1Н-хинолин-4-он), который изучают как перспективный антидепрессант с церебропротекторными, ноотропными, анальгетическими, антигипоксическими и актопротекторными свойствами. Обязательным условием дальнейшего внедрения его в качестве кандидата в лекарственные препараты является исследование фрармакокинетических характеристик молекулы. Это невозможно осуществить без целостного понимания процессов биотрансформации, которым подвергается исследуемое соединение в организме человека.

Цель исследования - провести in silico исследование возможных путей метаболизма перспективного антидепрессанта атристамина с помощью онлайн-ресурсов, находящихся в свободном доступе.

Методы исследования. С челью in silico исследования возможных направлений биотрансорормации атристамина в организме человека использовали он-лайн следующие веб-сервисы: "Xenosite P450 Metabolism 1.0"; "Хenosite UGT 2.0"; "Way2Drug SOMP" и "Way2Drug RA". Учитывая то, что структурной особен- 
ностью хинолин-4(1Н)-онов является возможность существования прототропной таутомерии в гетероцикле, вычисления проводили для обеих теоретически возможных таутомерных фрорм молекулы атристамина - 2-метил-3-(френиламинометил)-1Н-хинолин-4-она и 4-гидрокси-2-метил-3-(френиламинометил)-хинолина.

Результаты и обсуждение. Наличие вторичной аминогруппы в молекуле 2-метил-3-(фениламинометил)-1Н-хинолин-4-она и 4-гидроксигруппы в молекуле другого таутомера (4-гидрокси-2-метил-3- (френиламинометил)-хинолина) обусловливает высокую вероятность глюкуронирования с образованием, соответственно, N- и О-глюкуронидов. Для 2-метил-3-(френиламинометил)-1Н-хинолин-4-она как более устойчивой фоормы показано, что основными путями метаболизма могут быть ароматическое гидроксилирование, алифратическое гидроксилирование, окислительное дезаминирование, $N$-гидроксилирование и эпоксидирование. Наибольшего внимания заслуживает направление алифатического гидроксилирования, поскольку, в отличие от всех других путей, в результате этого прогнозируется образование генерации метаболитов с новыми фрармакологическими свойствами (производные кинуреновой кислоты).

Вывод. Результаты in silico исследования возможных путей метаболизма атристамина в организме человека свидетельствуют о том, что исследуемое соединение с высокой вероятностью интенсивно метаболизируется при участии энзимных систем цитохрома P450, что обязательно необходимо учесть в дальнейщем при планировании экспериментов in vivo.

КЛЮЧЕВЫЕ СЛОВА: атристамин; 2-метил-3-(френиламинометил)-1Н-хинолин-4-он; метаболизм; in silico исследование; Xenosite; Way2Drug.

I. M. Podolsky, S. Yu. Shtrygol

NATIONAL UNIVERSITY OF PHARMACY, KHARKIV

\section{IN SILICO RESEARCH OF THE POSSIBLE PATHWAYS OF ATRISTAMINE METABOLISM IN THE HUMAN BODY}

\section{Summary}

Introduction. The object of the present study is atristamine (2-methyl-3-(phenylaminomethyl)-1H-quinolin-4one), which is being studied as a promising antidepressant with cerebroprotective, nootropic, analgesic, antihypoxic and actoprotective properties. A prerequisite for its further introduction as a candidate for drugs is the study of the pharmacokinetic characteristics of the molecule. This is impossible without a holistic understanding of the biotransformation processes that the molecule undergoes in the human body.

The aim of the study - in silico study of the possible metabolic pathways of the promising antidepressant atristamine using freely available online resources.

Research Methods. For the purpose of in silico research of possible directions of biotransformation of atristamine in the human body, the following online web services were used: Xenosite P450 Metabolism 1.0; Xenosite UGT 2.0; Way2Drug SOMP and Way2Drug RA. Taking into account that the structural feature of quinolin-4(1H)-ones is the possibility of prototropic tautomerism in the heterocycle, computations were performed for both theoretically possible tautomeric forms of the atristamine molecule - 2-methyl-3-(phenylaminomethyl)-1H-quinolin-4-one and 4-hydroxy-2-methyl-3-(phenylaminomethyl)-quinoline.

Results and Discussion. Due to the presence of a secondary amino group in the molecule of 2-methyl-3(phenylaminomethyl)-1H-quinolin-4-one and 4-hydroxy group in the structure of another tautomer (4-hydroxy2-methyl-3-(phenylaminomethyl)-quinoline) glucuronidation is highly probable with the formation of $\mathrm{N}$ - and $\mathrm{O}$-glucuronides, respectively. For 2-methyl-3-(phenylaminomethyl)-1H-quinolin-4-one as a more stable form, it was shown that aromatic hydroxylation, aliphatic hydroxylation, oxidative deamination, $\mathrm{N}$-hydroxylation and epoxidation can be the main metabolic pathways. The direction of aliphatic hydroxylation deserves the most attention, since, unlike all other pathways, the formation of metabolites with new pharmacological properties (kynurenic acid derivatives) was predicted as a result of this.

Conclusions. The results of in silico research of possible pathways of atristamine metabolism in the human body support the fact that this molecule with high probability can be intensively metabolized via cytochrome P450 enzyme systems. This must be taken into account when planning in vivo experiments in the future.

KEY WORDS: atristamine; 2-methyl-3-(phenylaminomethyl)-1H-quinolin-4-one; metabolism; in silico research; Xenosite; Way2Drug.

Адреса для листування: І. М. Подольський, Національний ффармацевтичний університет, вул. Пушкінська, 53, Харків, 61002, Україна, e-mail: illya.podolsky@nuph.edu.ua. 